UDC 611.018.46

doi: https://doi.org/10.15407/ubj93.01.040

\title{
STROMAL-VASCULAR FRACTION OF ADIPOSE TISSUE AS AN ALTERNATIVE SOURCE OF CELLULAR MATERIAL FOR REGENERATIVE MEDICINE
}

\author{
A. S. SULTANOVA, O. Ya. BESPALOVA, O. Yu. GALKIN \\ National Technical University of Ukraine “Igor Sikorsky Kyiv Polytechnic Institute”; \\ e-mail:tmb@kpi.ua
}

Received: 06 August 2020; Accepted: 17 December 2020

\begin{abstract}
Adipose tissue is the most convenient source of cellular material for regenerative medicine as it can be obtained in significant quantities via cosmetic liposuction, lipoaspiration of subcutaneous fat or by excision of fat deposits. Adipose tissue consists of adipocytes and cells, which are the part of the stromal-vascular fraction (SVF). Different cell populations can be isolated from SVF, among which the population of adipose tissue stem cells (adipose-derived stem cells, ADSC) is especially important for regenerative medicine. SVF can be obtained relatively easily from adipose tissue (adipose tissue is an alternative to bone marrow in terms of being a source of stem cells) and used to treat various pathologies. Recent studies show that SVF not only has a therapeutic effect similar to that of ADSC, but in some cases is even more effective. The article provides the analysis of the main methods of SVF obtainment, characteristics of SVF cellular composition, its potential for use in clinical medicine and its main advantages over other sources of cellular material, including ADSC cultured in vitro, for regenerative medicine.
\end{abstract}

Ke y w o r d s: stromal-vascular fraction, adipose-derived stem cells, adipocytes, regenerative medicine.

\section{Methods of obtaining stromal- vascular fraction}

Enzymatic isolation of stromal-vascular fraction. Cleavage of fatty part of lipoaspirate by collagenase is the most common method of SVF isolation. After treatment with lipoaspirate collagenase and subsequent centrifugation the cell suspension is divided into two different phases: mature adipocytes are in the supernatant, and SVF with admixture of erythrocytes is in the sediment. To release SVF from erythrocytes, the sediment obtained after centrifugation is incubated in a lysing solution of ammonium chloride. In addition to centrifugation, it is possible to use the filtration method to extract SVF. Although centrifugation is a more efficient method of separation, all cells except adipocytes precipitate under such conditions, while filtration can be optimized to separate cells basing on their size, thereby enabling to control the content of individual cell populations in the pellet [1-3]. Enzymatic isolation of SVF can be performed manually or automatically. The principle of the manual method of SVF selection is presented in Fig. 1 [4].

Today, incubators, automatic shakers, cell filters and other devices are actively used in laboratories to obtain a cleaner fraction with a minimum amount of residual enzymes that adversely affect the further use of the resulting cell product. Additional washing steps in buffer solutions are introduced.

All manual methods are characterized by the fact that their implementation is time consuming and they also require significant organizational costs. They are also characterized by presence of so-called "human factor". Therefore, technologies for obtaining SVF are evolving in terms of process automation. Automatic and semi-automatic SVF selection systems have been created $[5,6]$.

The scheme of SVF allocation, using one of these systems, namely The Tissue Genesis Cell Isolation System (Tissue Genesis, Honolulu, HI, USA) is shown in Fig. 2 [7]. As can be seen from the figure, the final product is centrifuged after the applica-

(C) 2021 Sultanova A. S. et al. This is an open-access article distributed under the terms of the Creative Commons Attribution License, which permits unrestricted use, distribution, and reproduction in any medium, provided the original author and source are credited. 


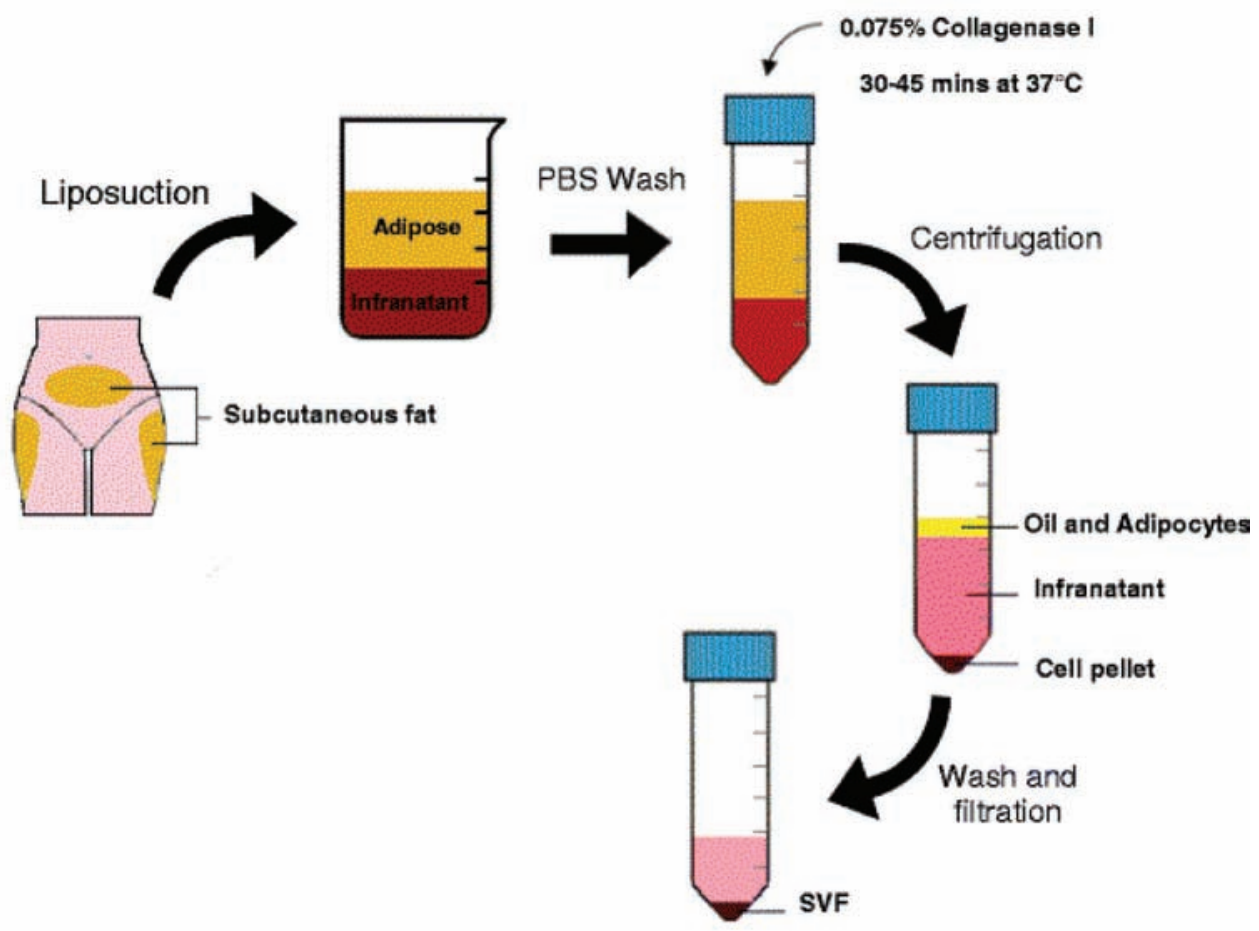

Fig. 1. General principle of manual selection of adipose tissue SVF [4]

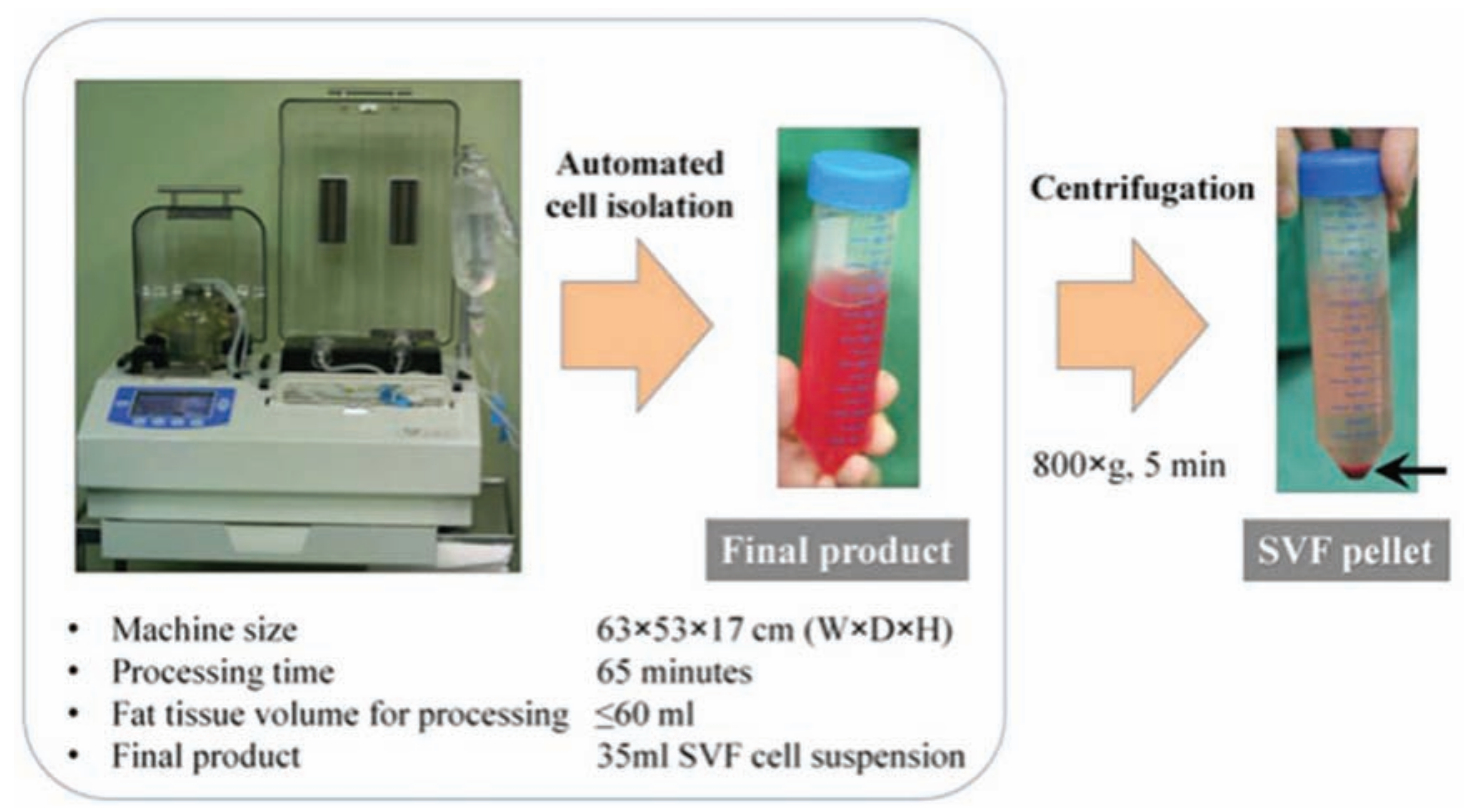

Fig. 2. Isolation of SVF from adipose tissue using an automatic system [7]

tion of this automatic system, and under these conditions SVF is in the sediment.

Almost all automatic separation systems consist of a stationary hardware and disposable sterile units. The sterile disposable unit, in turn, contains a tissue treatment chamber, where the processes of washing, enzyme treatment and centrifugation take place. Manufacturers include syringes in addition to collagenase and selection of prepared sample, enzymes, connecting tubes and also expendables in a complete set of disposable block, forming "individual set” (kit). 
In general, automatic SVF extraction systems emulate manual methods differing only in terms that all processes are pre-programmed and performed by hardware independently of laboratory assistant or researcher [5]. The use of such devices allows standardizing the selection protocol and significantly improvement of the quality and purity of the final product, but despite all the advantages such devices and consumables are very expensive and therefore inaccessible to most laboratories and patients.

Mechanical separation of stromal-vascular fraction. Given the regulatory issues related to enzymatic SVF isolation, it is important to consider alternative methods of SVF isolation. Most of these methods involve mechanical stirring, which destroys adipose tissue and releases stromal cells. As expected, the yield of cells in case of mechanical methods is much lower in comparison to enzymatic methods, because adipose tissue cells are tightly bound by collagen, which is the reason they are difficult to release in case of mechanical exposure [3]. New modification of the mechanical mixing method is based on the obtained injection product, which is called "nanofat". It is obtained by emulsification and filtration of lipoaspirate. By optimizing this method with the introduction of additional stages of centrifugation or filtration, you can get a product with a high concentration of ADSC in the absence of enzymatic cleavage, which reduces duration of the method and its cost, providing the possibility to circumvent regulatory restrictions on the use of collagenase in therapeutic products [8].

\section{Characteristics of the components of the stromal-vascular fraction.}

The adipose stromal vascular fraction is a heterogeneous population of cells that includes ADSC, endothelial progenitor cells (EPC), pericytes, smooth muscle cells, monocytes, erythrocytes and fibroblasts. The qualitative composition of SVF is presented in Fig. 3.

The figure shows that growth factors that secrete ADSC and EPC, such as insulin-like growth factor 1 (insulin-like growth factor 1, IGF-1), plate-

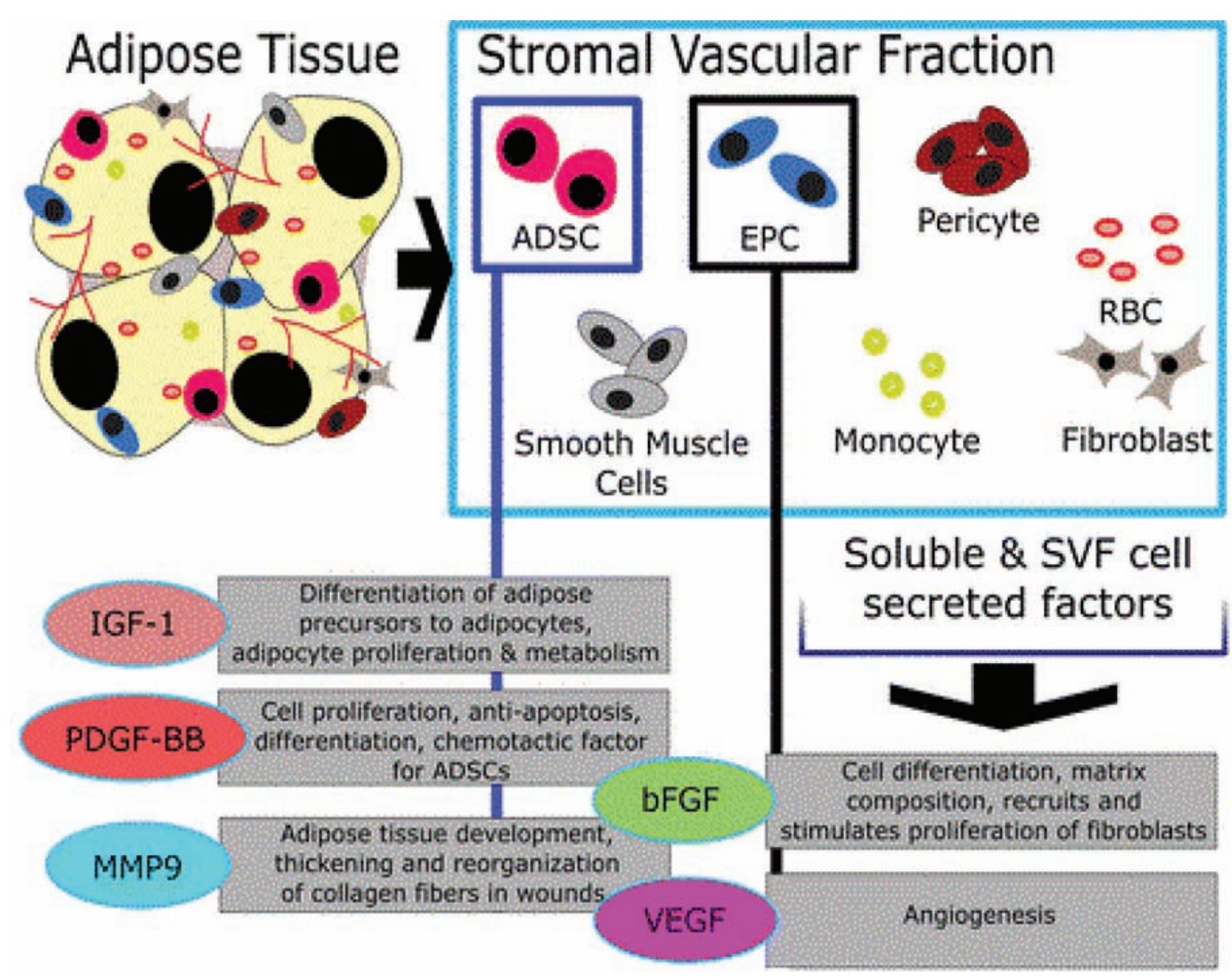

Fig. 3. Qualitative composition of SVF and growth factors that secrete cells that are part of it [3] 
let-derived growth factor-BB (platelet-Derived Growth Factor-BB, PDGF-BB), matrixmetallopeptidase 9 (matrixmetallopeptidase MMP9), basic fibroblast growth factor (basic fibroblast growth factor, bFGF), and vascular endothelial growth factor (vascular endothelial growth factor, VEGF) perform important functions in cell therapy [3].

Immunophenotyping, based on a system of cluster differentiation (CD), is used to characterize composition of SVF, i.e. by presence of marker mole- cules on cell membrane. The lists of positive and negative markers, that are most frequently used to identify different cell populations of SVF, are given in Table 1. This table also shows quantitative composition of SVF components.

Primary adipose tissue stem cell culture (ADSC) is a fairly homogeneous population of cells in comparison to heterogeneous SVF and is characterized by high expression of CD34 and the absence of CD31 (PECAM-1). When passing ADSC

Ta b le 1. Important components of SVF, their size, surface markers and percentage [3, 5]

\begin{tabular}{|c|c|c|c|c|}
\hline Cell type & Cell size & Positive markers & $\begin{array}{l}\text { Negative } \\
\text { markers }\end{array}$ & $\begin{array}{c}\text { Content in SVF, } \\
\%(M \pm \sigma)\end{array}$ \\
\hline $\begin{array}{l}\text { Stem cells of } \\
\text { adipose tissue }\end{array}$ & $\sim 10-25 \mu \mathrm{m}$ & $\begin{array}{l}\text { CD34, CD73, } \\
\text { CD13, CD90, } \\
\text { CD105, CD29 }\end{array}$ & $\begin{array}{l}\text { CD31, CD45, } \\
\text { CD144 }\end{array}$ & $34.6 \pm 17.8$ \\
\hline $\begin{array}{l}\text { Endothelial } \\
\text { progenitor cells }\end{array}$ & $\sim 7-8 \mu \mathrm{m}$ & $\begin{array}{l}\text { CD34, CD31, } \\
\text { CD133, CD146 }\end{array}$ & CD45 & $12.2 \pm 9.5$ \\
\hline Endothelial cells & $\sim 10-30 \mu \mathrm{m}$ & CD31, FVIII & CD34 & $2.7 \pm 0.8$ \\
\hline Regulatory T lymphocytes & $\sim 7-12 \mu \mathrm{m}$ & $\begin{array}{l}\text { CD4, CD25, } \\
\text { Foxp3, CD8 }\end{array}$ & - & $4.8 \pm 1.9$ \\
\hline Macrophages & $\sim 20 \mu \mathrm{m}$ & $\begin{array}{l}\text { CD45, CD14, } \\
\text { CD34, CD206 }\end{array}$ & - & $5.2 \pm 4.3$ \\
\hline Smooth muscle cells & $\begin{array}{c}\sim 3-20 \mu \mathrm{m} \text { in } \\
\text { width } \sim 20- \\
500 \mu \mathrm{m} \text { in length }\end{array}$ & $\begin{array}{l}\text { Smooth muscle } \\
\text { actin (SMA) }\end{array}$ & - & $\begin{array}{c}10.3 \pm 9.9 \text { (together } \\
\text { with pericytes) }\end{array}$ \\
\hline Pericytes & $\sim 70 \mu \mathrm{m}$ & $\begin{array}{l}\text { CD146, CD90, } \\
\text { CD73, CD44, } \\
\text { CD29, CD13 }\end{array}$ & $\begin{array}{l}\text { CD34, CD45, } \\
\text { CD56 }\end{array}$ & - \\
\hline Pre-adipocytes & $\sim 10 \mu \mathrm{m}$ & CD34 & $\begin{array}{c}\text { CD45, CD31, } \\
\text { CD146 }\end{array}$ & $0.5 \pm 0.3$ \\
\hline
\end{tabular}

Ta b le 2. Comparative characteristics of ADSC after isolation from adipose tissue in SVF and ADSC, cultured in vitro [3]

\begin{tabular}{|l|l|l|}
\hline \multicolumn{1}{|c|}{ Criterion } & \multicolumn{1}{|c|}{ ADSC in adipose tissue } & \multicolumn{1}{c|}{ ADSC cultured in vitro } \\
\hline $\begin{array}{l}\text { Surface } \\
\text { markers }\end{array}$ & CD34, CD73, CD90, CD13 & $\begin{array}{l}\text { CD73, CD90, CD13; (CD34 expression } \\
\text { decreases and stops under in vitro culture) }\end{array}$ \\
\hline Morphology & $\begin{array}{l}\text { Branched, with protrusions up to } 80 \mu \mathrm{m} \text { long, } \\
\text { form a grid surrounding mature adipocytes }\end{array}$ & $\begin{array}{l}\text { Typical elongated, stromal cell shape, } \\
\sim 10-25 \mu \mathrm{m} \text {, can reach } 200 \mu \mathrm{m}\end{array}$ \\
\hline $\begin{array}{l}\text { Functional } \\
\text { properties }\end{array}$ & $\begin{array}{l}\bullet \text { Support the growth of adipose tissue. } \\
\bullet \text { Can differentiate into mature adipocytes. }\end{array}$ & $\begin{array}{l}\bullet \text { Contribute and/or participate } \\
\text { in angiogenesis. } \\
\bullet \text { Possibility of differentiation in adipo-, } \\
\text { osteo- and chondrogenic directions. } \\
\bullet \text { Immunomodulatory properties. }\end{array}$ \\
\hline
\end{tabular}


slightly change their phenotype. Comparative characteristics of ADSC in SVF and ADSC, cultured in vitro, are given in Table. 2 .

Cultivation of SVF is usually used to separate fibroblast-like cells, so-called "sticky" (adhesive) fraction from other cells, as well as to increase the amount of ADSC via proliferation in nutrient medium. Technologies that exist today allow us to successfully achieve set goals, but they are timeconsuming, expensive and cost-ineffective, given the need to implement GMP (Good Manufacturing Practice) rules and regulations. In addition, cultivation may adversely affect the functional properties of cell graft due to changes in expression of adhesion molecules during cultivation, which in some cases makes it impossible to further use the cells in clinical practice. Cultivation can also adversely affect the differential potential of stem cells. Stem cells, isolated from adipose tissue, have the ability to proliferate in vitro, and their differentiation can be induced in adipogenic, osteogenic, chondrogenic and biogenic directions. In addition, the possibility of obtaining hepatocytes, endothelial cells, pancreatic cells that have the phenotype of endocrine cells, secreting that secrete insulin, was described as well as the possibility of their differentiation in the neurogenic direction. But it should also be mentioned that biological activity of the obtained cells in vivo still remains uncertain [5, 9-12].

\section{Application of stromal-vascular fraction in clinical medicine}

The first cases of SVF in clinical practice were registered in 2007-2008 in plastic surgery for mammoplasty, as well as for the treatment of radiation damage after radiation therapy in patients with breast cancer [3].

Plastic surgery. In order to improve the results in the use of lipotransfer (lipolifting, adipose tissue transplantation) in plastic and reconstructive surgery, the study of new ways to effectively use this method was conducted. Clinicians are currently investigating the problem of preserving adipose tissue after transplantation. Resorption rates under these conditions range from 25 to $80 \%$. Most of the losses are due to the fact that there is cell death of mature adipocytes after injection of lipoaspirate to the recipient. The survival of fat cells depends on their location in the graft: adipocytes survive more often on the periphery, while necrosis is observed in the center. Peripheral zone of the graft is the zone of re- generation, where ADSC stimulate the replacement and survival of adipocytes. The highest ration of cell death is observed in the center, being the result of ischemia and poor tissue oxygenation [13, 14].

The concept of lipotransferases by helper cells (cell-assisted lipotransfer, CAL) was developed. It is based on the use of SVF, which was obtained immediately before the procedure. According to this concept, SVF is combined with a pre-prepared fat graft, which acts as a framework for SVF. The fat graft, containing SVF, led to a 35\% increase in graft preservation after transplantation and had more pronounced microcirculatory tract than the fat graft without SVF. Initially, these studies were performed in mice, but since then the efficacy and safety of CAL in plastic surgery have been demonstrated. After administration of $270 \mathrm{ml}$ of CAL there was an increase in breast volume by $100-200 \mathrm{ml}$, with the structure and contours of the breasts being natural; most patients were satisfied with the result. Clinical efficacy of CAL application has also been demonstrated in the use for facial contouring and soft tissue augmentation in patients with hemafacial microsomia. In all these cases, there was a substantial reduction in fat graft loss $[15,16]$.

Rheumatoid arthritis. Experimental studies in mice with collagen-induced arthritis (experimental model of rheumatoid arthritis) have shown that use of mesenchymal stem cells leads to remission of the disease and regeneration of cartilage [17].

Studies have been performed in people with rheumatoid arthritis who were treated with SVF, which was isolated immediately before treatment and was not pre-cultured in vitro. Thirteen patients with rheumatoid arthritis received $38 \cdot 10^{6}-148 \cdot 10^{6}$ SVF cells intravenously and intra-articularly in one study. However, side effects were observed in one patient who reported facial flushing, fever, and myalgia after the third SVF injection out of four.

However, all these symptoms passed spontaneously after some time [18]. Another study involved 5 patients with rheumatoid arthritis who received an intra-articular injection of SVF (an average of 30.106 cells per arm) into the interphalangeal joints of the hand. These studies have shown that the use of SVF reduces joint pain and improves their mobility. It has been concluded that the use of SVF-based therapy in the early stages of rheumatoid arthritis may stop or slow down the progression of the disease [19].

Nerve tissue damage. Studies have shown that ADSC, like SVF, stimulates peripheral nerve re- 
generation. While the efficacy of ADSC in a mouse model to has been demonstrated in terms of nerve tissue regeneration, the use of a heterogeneous population of SVF cells is also promising. The use of SVF that was not cultured in vitro showed significant improvement of nerve tissue regeneration in vivo when modeling sciatic nerve incision. In animals injected with SVF, there was an increased functional activity of nervous tissue, a decrease in the time of restoration of its functioning and an increase in muscle mass compared with the control group. Immunohistochemical studies of the damaged nerve also showed that SVF transplantation increased the number of Schwann cells compared to normal nerve repair. Subsequently, there was a significant increase in the diameter of axon, nerve fiber and thickness of myelin sheath. Promising results of this study show that SVF can enhance nerve regeneration by providing tissue with extracellular matrix proteins and factors that support Schwann cell proliferation and axon growth [20].

Multiple sclerosis is a chronic autoimmune disease in which patient's own immune cells attack the myelin sheaths of nerve fibers of the brain and spinal cord. Experimentally induced demyelinating disease, experimental autoimmune encephalitis, is often used to model multiple sclerosis in animals. Animal studies, aimed at examining the effects of SVF and ADSC on a model of experimental autoimmune encephalitis, suggest that SVF may be used in clinical practice for treatment of multiple sclerosis.

The efficacy of ADSC, cultured in vitro, and SVF in the treatment of chronic experimentallyinduced demyelinating disease was compared. In both cases, there was a decrease in demyelination and concentration of decomposition products, which are usually observed in the course of this disease. From this we can conclude that ADSC and SVF have neuroprotective properties that reduce severity of the disease. However, SVF injection is more effective than ADSC injection in terms of delaying the onset of experimentally-induced demyelinating disease [21, 22].

Burns. Skin transplantation today is the main method of treatment of severe burns. However, skin transplantation has several disadvantages, which include rejection of the graft by recipient's immune system and low preservation of the transplanted skin due to low vascularization, hematomas and infections. Increasing the rate of graft vascularization accelerates the healing. The use of a heterogeneous population of SVF instead of ADSC that have been cultured in vitro may demonstrate greater benefits and better efficacy in healing burns via involving other cell types and growth factors, present in SVF.

Due to their autologous origin SVF cells can improve the healing of burns when transplanted to the wound surface by stimulating the recipient cells as well as by isolating growth factors and extracellular matrix.

Experiments on rats have shown that the administration of SVF by intradermal injection can accelerate and improve healing of severe burns. SVF was found to increase vascularization and fibroblastic activity in the treated skin, as well as reduce inflammation and increase cell proliferation compared to controls in rats [23, 24].

Diabetes. The ability of SVF to stimulate tissue regeneration extends to serious complications of diabetes, namely diabetic foot syndrome, nephropathy and retinopathy. The ulcer that develops in case of diabetic foot syndromes is one of the most common complications that develop on the basis of diabetic neuropathy as well as micro- and macroangiopathy. This condition is complicated by the appearance of various infections. In in vitro studies, SVF has been proven to significantly increase the proliferation (28\%) of diabetic foot fibroblasts, which are the major cellular components, involved in wound healing. In addition, there also has been an increase in collagen synthesis (by $44 \%$ ) by fibroblasts, a process that is important for extracellular matrix synthesis. Immediately after in vitro studies clinical trials were conducted, that demonstrated that SVF accelerated wound healing when SVF cells were dispersed on the ulcer itself (autograft). The authors noted complete wound healing in $100 \%$ of patients, receiving SVF, in contrast to $62 \%$ in the control group. It has been suggested that SVF is able to secrete growth factors and extracellular matrix to improve the regenerative microenvironment [13, 23].

Different populations of adipose tissue macrophages in SVF were characterized, and it was determined that more than $90 \%$ of adipose tissue macrophages are present in the activated state, namely M2 type macrophages. It has been suggested that the anti-inflammatory properties of the M2-type macrophage phenotype also contribute to the efficacy of SVF therapy in diabetic foot ulcers.

Another common complication of diabetes is retinopathy, which is characterized by dysfunction and degeneration of small vessels of the retina. It has 
been hypothesized that cells that make up SVF, such as endothelial progenitor cells, may contribute to retinal repair. This hypothesis is based on the results of experimental studies in mice.

A study was performed in which rats, in which diabetes mellitus was induced, were administered with ADSC, under conditions of which a reduction in vascular degeneration and apoptosis was observed. It has been suggested that interaction of ADSC with retinal endothelial cells promotes vascular formation and prevents neurodegeneration. In addition, the ability of stem cells to cure kidney damage in rats with diabetic nephropathy has been demonstrated [25].

Radiation damage. The most common side effects of radiation therapy (radiotherapy) include changes in the blood supply to the blood vessels and their damage, which can lead to ischemia in the tissue being treated, as well as tissue desquamation, erythema, edema, fibrosis and necrosis. The effects of heterogeneous lipoaspirate injection for treatment of the patients, undergoing radiation therapy, and in whom severe or irreversible functional tissue damage has been observed, have been studied. Injection of lipoaspirate into tissue that was damaged by radiotherapy led to increased neovascularization with increased hydration, perfusion and oxygenation of the tissue.

Neovascularization resulting from SVF injection has in turn supplanted unwanted vascularization and fibrosis, caused by radiation therapy. As a result, transformational changes were observed after SVF injection in fibrous tissue, damaged by radiotherapy. In this case, patients showed a sharp improvement in general condition with a decrease in symptoms [26].

Crohn's disease. Along with breast reconstruction, treatment of Crohn's disease is one of the most common uses of SVF in clinical therapy. Crohn's disease is a chronic nonspecific granulomatous inflammation of gastrointestinal tract. Clinical signs of this disease are many symptoms, ranging from abdominal pain to bloody diarrhea and severe weight loss. Although the exact cause of Crohn's disease is still unknown, the findings suggest that the main causes of the disease are genetic and immunological factors as well as environmental factors.

SVF in vitro and in clinical trials has demonstrated the efficacyfor treatment of fistulas, resulting from Crohn's disease. In vitro studies show that mesenchymal stem cells (MSCs) have the ability to inhibit alloreactivity of T-lymphocytes, which is the main characteristic of Crohn's disease. This effect is possible due to MSC's ability to immunoregulate its immediate microenvironment, a property that has been found in other SVF cells, including the M2 macrophage type. In human studies, MSCs were administered systemically and locally to patients with Crohn's disease. The results of therapy, based on the use of MSCs, have demonstrated the safety and efficacy of their use, but further clinical trials are needed to identify the optimal therapeutic dose and method of MSCs administration [27]. Thus, although there is currently no definitive cure for Crohn's disease, cell therapy using SVF and its components is a promising treatment.

Bone damage. ADSC have proven to be highly effective in stimulating bone regeneration and healing in vivo in animal studies as well as in human clinical trials. A cranioplasty procedure was performed on four patients using ADSC, which was seeded in a framework of calcium $\beta$-orthophosphate granules ( $\beta$-tricalciumphosphate, $\beta$-TCP).

Under these conditions, positive results of osteogenesis (ossification) were observed in the absence of clinical complications. In another study, $10 \mathrm{~cm}$ of a defective anterior mandible was replaced, using a $\beta$-TCP-based framework, recombinant human bone morphogenetic protein-2 (BMP-2) and ADSC. In order to fully form the implant for further transplantation, it was left for ten months after which there was a final ossification of the graft with its subsequent successful transplantation to the donor [28]. In addition to inducing bone formation, it is believed that ADSC also accelerate bone healing by being directly introduced into the area where the bone defect is present [13].

SVF together with recombinant human BMP-2 demonstrated the osteogenic potential to induce SVF cell differentiation into osteogenic cell lines with the formation of new bone tissue. In addition, studies were performed in order to compare the degree of correction of osteochondral defect that was simulated in the knees of goats, using SVF, seeded on collagen skeletons, which was isolated immediately before use, or ADSC, which were pre-cultured in vitro. According to studies, the degree of bone regeneration in bones, seeded with SVF cells or ADSC cultured in vitro, was quite similar. In both cases, no side effects were observed. Under these conditions, both groups of carcasses, seeded with SVF or ADSC, showed higher degree of regeneration compared to control carcasses that were not previously seeded with stem cells [29]. 
These studies have shown that ADSC and SVF can have the potential to be transplanted into damaged bone to facilitate its repair and regeneration. This has increased the interest of researchers in the ability of SVF to differentiate in the osteogenic direction and its use in orthopedic procedures. To date, several clinical trials have been conducted to investigate the therapeutic use of SVF and ADSC in human bone repair.

Heart disease. Many studies have attempted to use ADSC and bone marrow stem cells to treat various heart conditions. The therapeutic value of ADSC transplantation for treatment of myocardial infarction is limited. Provided that only ADSC are implanted directly into the heart muscle, poor long-term cell engraftment and survival is reported. Given the heterogeneity of SVF, in which there are different cell populations, its use may be more effective than the treatment with ADSC alone. A study was conducted, in which rats with induced acute myocardial infarction were injected intravenously with SVF or ADSC, which were cultured in vitro. A significant reduction in the size of the infarct area was observed in both groups treated. No side effects were observed in rats injected with SVF, whereas in rats, injected with ADSC, dyspnoea (dyspnea) was observed in three cases, and one animal died during the injection $[13,30]$. These results imply that SVF that was isolated immediately before treatment may have the same regenerative potential as previously cultured in vitro ADSC, possibly with fewer side effects.

An example of the clinical use of SVF for the treatment of heart disease is the case of intramyocardial and intravenousl SVF injections in a 73-year-old man with refractory angina. SVF cells have proven to be effective in repairing damaged myocardium, and cardiac function has been partially restored, as evidenced by the ejection fraction, which improved from $20 \%$ to $35 \%$ in just 7 days [31]. The ability of SVF to repair damaged heart tissue demonstrates the potential for its use in cardiology.

\section{Advantages of stromal-vascular fraction over other sources of cellular material for regenerative medicine}

The results of studies using human bone marrow cell transplantation in patients with ischemia imply that introduction of $10^{7}$ to $10^{9}$ endothelial progenitor cells from peripheral or umbilical cord blood is required in order to stimulate angiogenesis in humans, depending on the degree of purity of stem cells and their delivery. The need for a large amount of patient's blood required to achieve a proangiogenic effect is the result of the fact that in the peripheral blood there is a small number of endothelial progenitor cells., It is difficult to obtain a given number of cells under clinical conditions. A study was conducted to compare the release of endothelial progenitor cells from bone marrow and adipose tissue. It has shown that a higher number of endothelial progenitor cells can be obtained from adipose tissue than from peripheral blood [32].

In addition, a comparison of bone marrow stem cells and the ones from adipose tissue obtained from the same donor showed that fewer cells were required to achieve transfusion for 1 week in case of ADSC culture than in case of bone marrow cell culture [33]. This indicates a greater proliferative potential of ADSC. From this we can conclude that higher proliferative activity of stem cells, derived from adipose tissue, generates a clinically effective dose of cells faster, than in case of using bone marrow cells with the same functional properties. Studies have

Ta b le 3. Comparative characteristics of SVF and ADSC, cultured in vitro [3]

\begin{tabular}{|l|c|c|}
\hline \multicolumn{1}{|c|}{ Criterion } & SVF & ADSC \\
\hline Cell population & Heterogeneous & Homogeneous \\
\hline Cell types & ADSC, EPC etc. & Autologous, allogeneic \\
\hline Application & Autologous & Not expected \\
\hline Immune rejection reaction & $\begin{array}{c}\text { Angiogenic, immunomodulatory } \\
\text { activity, ability to differentiate }\end{array}$ & $\begin{array}{c}\text { Immunomodulatory activity, } \\
\text { ability to differentiate }\end{array}$ \\
\hline Properties & hour & Weeks \\
\hline $\begin{array}{l}\text { Duration of exposure } \\
\text { to the material ex vivo }\end{array}$ & & Immolical monitoring is required \\
\hline
\end{tabular}


also shown that stem cells, isolated from SVF, have more pronounced immunomodulatory effect (inhibit immunoglobulin production and inhibit B-lymphocyte function) than bone marrow stem cells [34].

Comparison of SVF adipose tissue and ADSC, cultured in vitro, are given in Table 3.

SVF has certain advantages over ADSC cultured in vitro. First, although they are similar in functional properties, such as immunomodulatory and anti-inflammatory activity and stimulation of angiogenesis, the heterogeneous composition of SVF may be the reason that comparative studies in animals with SVF show better therapeutic results. Secondly, unlike ADSC, SVF is much easier to obtain without the need for cell separation and culture, which is the reason that such therapeutic product can be obtained instantly and at the same time it will have minimal contact with reagents, which makes it relatively safer for use in clinical practice. However, it should be noted that while ADSC is used for both autologous and allogeneic treatment, SVF, is suitable only for autologous treatment due to the presence of different cell types, that cause immunological rejection, in its composition [3, 35, 36].

Conclusions. Stromal vascular fraction (SVF) of adipose tissue is a heterogeneous population of cells that consists of ADSC, endothelial progenitor cells, pericytes, smooth muscle cells, monocytes, erythrocytes and fibroblasts.

The most common method of SVF isolation is cleavage of fatty part of lipoaspirate by collagenase, which can be performed manually or automatically. There are also alternative methods of obtaining SVF, the majority of which are based on mechanical mixing of lipoaspirate.

Presently studies are being conducted on the use of SVF for treatment of patients with soft tissue defects, skeletal bones damagechronic trophic and radiation ulcers, burns, Crohn's disease, multiple sclerosis, myocardial infarction, etc.

Relative simplicity, low injury rate of the procedure for obtaining adipose tissue and the possibility of isolating a significant number of stem cells allow us to consider SVF as a promising object for autologous transplantation.

Conflict of interest. Authors have completed the Unified Conflicts of Interest form at http://ukrbiochemjournal.org/wp-content/uploads/2018/12/ coi_disclosure.pdf and declare no conflict of interest.
Funding. The work was conducted on the project "Development of innovative biomedical technologies and products for the diagnosis and treatment of human pathologies" (\#0119U103789) at the Igor Sikorsky Kyiv Polytechnic Institute.

\section{СТРОМАЛЬНО-ВАСКУЛЯРНА ФРАКЦІЯ ЖИРОВОЇ ТКАНИНИ ЯК АЛЬТЕРНАТИВНЕ ДЖЕРЕЛО КЛІТИННОГО МАТЕРІАЛУ ДЛЯ РЕГЕНЕРАТИВНОЇ МЕДИЦИНИ}

\section{А. С. Султанова, О. Я. Беспалова, О. Ю. Галкін}

$$
\begin{gathered}
\text { Національний технічний університет } \\
\text { України «Київський політехнічний } \\
\text { iнститут імені Ігоря Сікорського»; } \\
\text { e-mail: tmb@kpi.ua }
\end{gathered}
$$

Жирова тканина $є$ найзручнішим джерелом клітинного матеріалу для регенеративної медицини, оскільки вона може бути отримана в значній кількості шляхом косметичної ліпосакції, ліпоаспірації або шляхом ексцизії жирових відкладень. До складу жирової тканини входять адипоцити, а також клітини, що є складовими гетерогенної стромально-васкулярної фракції (stromal-vascular fraction, SVF), з якої можна виділити різні популяції клітин. Серед них найважливішою для регенеративної медицини є популяція стовбурових клітин адипозної тканини (adipose-derived stem cells, ADSC). SVF можна відносно легко отримати із жирової тканини (ця тканина $\epsilon$ альтернативою кістковому мозку як джерело стовбурових клітин) і використати для лікування різних патологій. Результати досліджень показали, що SVF не тільки має схожий до ADSC терапевтичний ефект, але в деяких випадках $\epsilon$ навіть ефективнішим. В огляді розглянуто основні методи одержання та клітинний склад SVF, потенціал застосування в клінічній медицині, основні переваги перед іншими джерелами клітинного матеріалу для регенеративної медицини, зокрема, перед ADSC, що культивуються in vitro.

К л ю чо в і с ло в а: стромально-васкулярна фракція, стовбурові клітини, жирова тканина, адипоцити, регенеративна медицина. 


\section{References}

1. Ramakrishnan VM, Boyd NL. The Adipose Stromal Vascular Fraction as a Complex Cellular Source for Tissue Engineering Applications. Tissue Eng Part B Rev. 2018; 24(4): 289-299.

2. Zuk PA, Zhu M, Mizuno H, Huang J, Futrell JW, Katz AJ, Benhaim P, Lorenz HP, Hedrick MH. Multilineage cells from human adipose tissue: implications for cell-based therapies. Tissue Eng. 2001; 7(2): 211-228.

3. Bora P, Majumdar AS. Adipose tissue-derived stromal vascular fraction in regenerative medicine: a brief review on biology and translation. Stem Cell Res Ther. 2017; 8(1): 145.

4. Ciervo Y, Ning K, Jun X, Shaw PJ, Mead RJ. Advances, challenges and future directions for stem cell therapy in amyotrophic lateral sclerosis. Mol Neurodegener. 2017; 12(1): 85.

5. Veremeev AV, Bolgarin PN, Petkova MA, Katz N, Nesterenko VG. Stromal-vascular adipose tissue fraction as an alternative source of cellular material for regenerative medicine. Genes Cells. 2016; 11(1): 35-42.

6. Zhu M, Heydarkhan-Hagvall S, Hedrick M, Benhaim P, Zuk P. Manual isolation of adiposederived stem cells from human lipoaspirates. $J$ Vis Exp. 2013; (79): e50585.

7. Doi K, Tanaka S, Iida H, Eto H, Kato H, Aoi N, Kun S, Hirohi T, Yoshimura K. Stromal vascular fraction isolated from lipo-aspirates using an automated processing system: bench and bed analysis. $J$ Tissue Eng Regen Med. 2013; 7(11): 864-870.

8. Tonnard P, Verpaele A, Peeters G, Hamdi M, Cornelissen M, Declercq H. Nanofat grafting: basic research and clinical applications. Plast Reconstr Surg. 2013; 132(4): 1017-1026.

9. Mizuno H, Tobita M, Uysal AC. Concise review: Adipose-derived stem cells as a novel tool for future regenerative medicine. Stem Cells. 2012; 30(5): 804810.

10. Galkin A, Komar A, Gorshunov Yu, Besarab A, Soloviova V. New monoclonal antibodies to the prostate-specific antigen: obtaining and studying biological properties. J Microbiol Biotech Food Sci. 2019; 9(3): 573-577.

11. Grigorieva SM, Starosyla DB, Rybalko SL, Motronenko VV, Lutsenko TM, Galkin OYu. Effect of recombinant human interleukin-7 on Pseudomonas aeruginosa wound infection. Ukr Biochem J. 2019; 91(5): 7-15.

12. Nikolayenko IV, Galkin AYu, Rayevskaya GYe, Kas'ianenko TV, Tereshchenko MI, Donskaya YeS, Spivak NYa. Preparation of monoclonal antibodies to the Fc-fragment of human IgG and the use of their based immunoenzyme conjugates. Klin Lab Diagn. 2005; (11): 8-11. (In Russian).

13. Nguyen A, Guo J, Banyard DA, Fadavi D, Toranto JD, Wirth GA, Paydar KZ, Evans GR, Widgerow AD. Stromal vascular fraction: A regenerative reality? Part 1: Current concepts and review of the literature. J Plast Reconstr Aesthet Surg. 2016; 69(2): 170-179.

14. Motronenko V, Lutsenko T, Galkin A, Gorshunov Y, Solovjova V. Optimization of the culture medium composition to increase the biosynthesis of recombinant human interleukin-7 in Escherichia coli. J Microbiol Biotech Food Sci. 2020; 9(4): 761768.

15. Kølle SF, Fischer-Nielsen A, Mathiasen AB, Elberg JJ, Oliveri RS, Glovinski PV, Kastrup J, Kirchhof M, Rasmussen BS, Talman ML, Thomsen C, Dickmeiss E, Drzewiecki KT. Enrichment of autologous fat grafts with ex-vivo expanded adipose tissue-derived stem cells for graft survival: a randomised placebo-controlled trial. Lancet. 2013; 382(9898): 1113-1120.

16. Lutsenko TN, Kovalenko MV, Galkin OYu. Validation of biological activity testing procedure of recombinant human interleukin-7. Ukr Biochem J. 2017; 89(1): 82-89.

17. MacDonald GI, Augello A, De Bari C. Role of mesenchymal stem cells in reestablishing immunologic tolerance in autoimmune rheumatic diseases. Arthritis Rheum. 2011; 63(9): 2547-2557.

18. Rodriguez JP, Murphy MP, Hong S, Madrigal M, March KL, Minev B, Harman RJ, Chen CS, Timmons RB, Marleau AM, Riordan NH. Autologous stromal vascular fraction therapy for rheumatoid arthritis: rationale and clinical safety. Int Arch Med. 2012; 5: 5 .

19. Carstens M, Montenegro JJ, Gomez A, Correa D. Adipose-derived stromal vascular fraction (SVF) cells in the treatment of rheumatoid arthritis of the hand. CellR4. 2018; 6(3): e2533.

20. Mohammadi R, Sanaei N, Ahsan S, Rostami H, Abbasipour-Dalivand S, Amini K. Repair of nerve defect with chitosan graft supplemented by uncultured characterized stromal vascular fraction in streptozotocin induced diabetic rats. Int J Surg. 2014; 12(5): 33-40.

21. Semon JA, Zhang X, Pandey AC, Alandete SM, Maness C, Zhang S, Scruggs BA, Strong AL, Sharkey SA, Beuttler MM, Gimble JM, Bunnell BA. Administration of murine stromal vascular fraction ameliorates chronic experimental autoimmune encephalomyelitis. Stem Cells Transl Med. 2013; 2(10): 789-796.

22. Galkin $\mathrm{OYu}$, Gorshunov $\mathrm{YuV}$, Besarab OB, Ivanova OM. Development and characterization of highly informative ELISA for the detection of IgG 
and IgA antibodies to Chlamydia trachomatis. Ukr Biochem J. 2018; 90(3): 70-83.

23. You HJ, Han SK. Cell therapy for wound healing. $J$ Korean Med Sci. 2014; 29(3): 311-319.

24. Sokol AA, Grekov DA, Yemets GI, Galkin AYu, Shchotkina NV, Dovghaliuk AA, Telehuzova OV, Rudenko NM, Romaniuk OM, Yemets IM. Comparison of bovine pericardium decellularization protocols for production of biomaterial for cardiac surgery. Biopolym Cell. 2020; 36(5): 392-403.

25. Lv SS, Liu G, Wang JP, Wang WW, Cheng J, Sun AL, Liu HY, Nie HB, Su MR, Guan GJ. Mesenchymal stem cells transplantation ameliorates glomerular injury in streptozotocin-induced diabetic nephropathy in rats via inhibiting macrophage infiltration. Int Immunopharmacol. 2013; 17(2): 275-282.

26. Rigotti G, Marchi A, Galiè M, Baroni G, Benati D, Krampera M, Pasini A, Sbarbati A. Clinical treatment of radiotherapy tissue damage by lipoaspirate transplant: a healing process mediated by adiposederived adult stem cells. Plast Reconstr Surg. 2007; 119(5): 1409-1422.

27. Dalal J, Gandy K, Domen J. Role of mesenchymal stem cell therapy in Crohn's disease. Pediatr Res. 2012; 71(4 Pt 2): 445-451.

28. Sándor GK, Tuovinen VJ, Wolff J, Patrikoski M, Jokinen J, Nieminen E, Mannerström B, Lappalainen OP, Seppänen R, Miettinen S. Adipose stem cell tissue-engineered construct used to treat large anterior mandibular defect: a case report and review of the clinical application of good manufacturing practice-level adipose stem cells for bone regeneration. J Oral Maxillofac Surg. 2013; 71(5): 938-950.

29. Jurgens WJ, Kroeze RJ, Zandieh-Doulabi B, van Dijk A, Renders GA, Smi TH, van Milligen FJ, Ritt MJ, Helder MN. One-step surgical procedure for the treatment of osteochondral defects with adiposederived stem cells in a caprine knee defect: a pilot study. Biores Open Access. 2013; 2(4): 315-325.

30. Golembiovska O.I., Galkin A.Yu., Besarab A.B. Development and validation of a dissolution test for ursodeoxycholic acid and taurine from combined formulation. Sci Study Res Chem Chem Eng Biotechnol Food Industry. 2019; 20(3): 377-394.

31. Khalpey Z, Janardhanan R, Konhilas J, Hemphill C. First in man: adipose-derived stromal vascular fraction cells may promote restorative cardiac function. Am J Med. 2014; 127(5): e11-e12.

32. Madonna R, Geng YJ, De Caterina R. Adipose tissuederived stem cells: characterization and potential for cardiovascular repair. Arterioscler Thromb Vasc Biol. 2009; 29(11): 1723-1729.

33. De Ugarte DA, Morizono K, Elbarbary A, Alfonso Z, Zuk PA, Zhu M, Dragoo JL, Ashjian P, Thomas B, Benhaim P, Chen I, Fraser J, Hedrick MH. Comparison of multi-lineage cells from human adipose tissue and bone marrow. Cells Tissues Organs. 2003; 174(3): 101-109.

34. McIntosh K, Zvonic S, Garrett S, Mitchell JB, Floyd ZE, Hammill L, Kloster A, Di Halvorsen Y, Ting JP, Storms RW, Goh B, Kilroy G, Wu X, Gimble JM. The immunogenicity of human adiposederived cells: temporal changes in vitro. Stem Cells. 2006; 24(5): 1246-1253.

35. Nikolaenko IV, Goncharenko VS, Shimko NN, Galkin AYu. Isolation of surface antigen of hepatites B virus. Ukr Biokhim Zhurn. 2007; 79(2): 114-122. (In Russian).

36. Prokopiuk VYu, Globa NS, Prokopiuk OS, Shchedrov AO, Musatova IB. Characterization of placental mesenchymal stem cells spheroids after generation, hypothermic and subnormothermic storage. Innov Biosyst Bioeng. 2019; 3(3): 146-151. 